SHS Web of Conferences 12, 01095 (2014)

DOI: $10.1051 /$ shsconf/ 20141201095

(C) Owned by the authors, published by EDP Sciences, 2014

\title{
An Assessment on Destination Characteristics: The Case Study of Pulau Perhentian
}

\author{
Masitah Muhibudin ${ }^{1}$, Badaruddin Mohamed $^{2}$ \\ ${ }^{1}$ Sustainable Tourism Research Cluster, Universiti Sains Malaysia, 11800 Penang, Malaysia \\ ${ }^{2}$ School of Housing, Building and Planning, Universiti Sains Malaysia, 11800 Penang, Malaysia
}

\begin{abstract}
The growth of tourism in the small island has brought both positive and negative impacts towards the environment particularly. However, the growth seems disregard with the limited natural resources, facilities, accessibilities and others. Pulau Perhentian, one of the well known islands in Malaysia that is struggling with many physical carrying capacity related issues such as waste management, supply of accommodation, utilities, facilities and environmental protection. Consequently, this study aims to evaluate the destination characteristics that contribute to the management of physical carrying capacity using the criteria matrix. Finding shows that the physical development has marked the island into a yellow colour that indicates the condition of current development. This evaluation is hoped to contribute and assist in future tourism activities and physical developments in Perhentian.
\end{abstract}

\section{Introduction}

Malaysia has many beautiful and peaceful islands. In fact, Malaysia is one of the leading dive destinations of the world with the richest marine environment in the Indo-Pacific Basin [1]. These islands are protected and monitored by the Department of Marine Park Malaysia. By law, there are two laws applied and important to marine protected areas namely the Environmental Quality Act 1974 and Fisheries Act 1985 [2]. Today, there are 42 islands in Malaysia that have been gazetted as Marine Park since 1985 with the aims to protect and conserve various habitats and aquatic marine life. Marine Park is a sea zoned area for a distance of two nautical miles from the lowest sea level, and a conservation fee will be charged upon entrance [3]. The marine park status has boosted up these islands as tourist destinations worldwide. Since that, tourist arrivals to these islands are increasing hugely. Figure 1 shows the number of tourists in the marine park in Peninsular Malaysia in year 2000 until 2013. Although the figure indicates several drops in the year 2003, 2005, 2007 and 2011, yet the total has increased about $63 \%$ within that period. As a result, many physical structures like jetty, chalets, luxury resorts and hotels are being developed rapidly along the coastlines as to accommodate with the demand. Most of the islands are faced with the same situation including Perhentian.

Pulau Perhentian is one of the thirteen gazette islands in Terengganu [3] and become one of the fabulous marine parks in Malaysia. It is a group of islands comprises of Perhentian Besar (the largest island), Perhentian Kecil (the smaller), Rawa, Serenggeh, Susu Dara Besar and Susu Dara Kecil. However, only two islands are inhabited; Besar and Kecil with total area 1,392.15 hectares approximately. This island is located in the South China Sea, which is about 10.8 nautical miles (20 kilometres) from Kuala Besut Jetty on the mainland and can be reached by 45 minutes boat ride from 
there. Perhentian literally means a stopover. Historically, it was opened by Batin Mina and his family from the Riau Archipelago by the end of the $18^{\text {th }}$ century. This island always became a stopover by the traders from China who sailed from China to the South East Asia and therefore it is named as Perhentian [4]. Today, it has no longer become a stopover by traders, but an ideal place for a relaxing holiday. It has turned as a tourism destination since the late 1980s when backpackers discovered these islands [5]. Moreover, the magnificent dive sites around this island become the pull factor for tourists especially divers to stay in. As suggested, the best time to visit this island is from March to October because most of the resorts are closed during monsoon season, which begins in November until February [1]. Although this island is open for several months only each year, yet it receives a great number of tourists every year which is exceedingly.

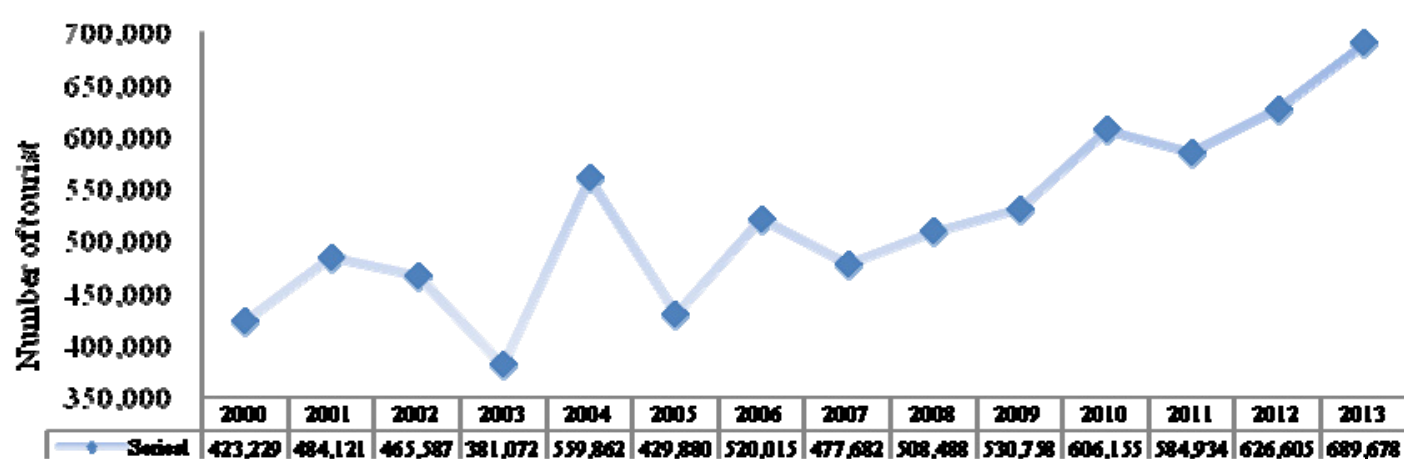

Figure 1. Number of visitors/ tourist to Marine Park in Peninsular Malaysia from 2000 until 2013 Source: [3]

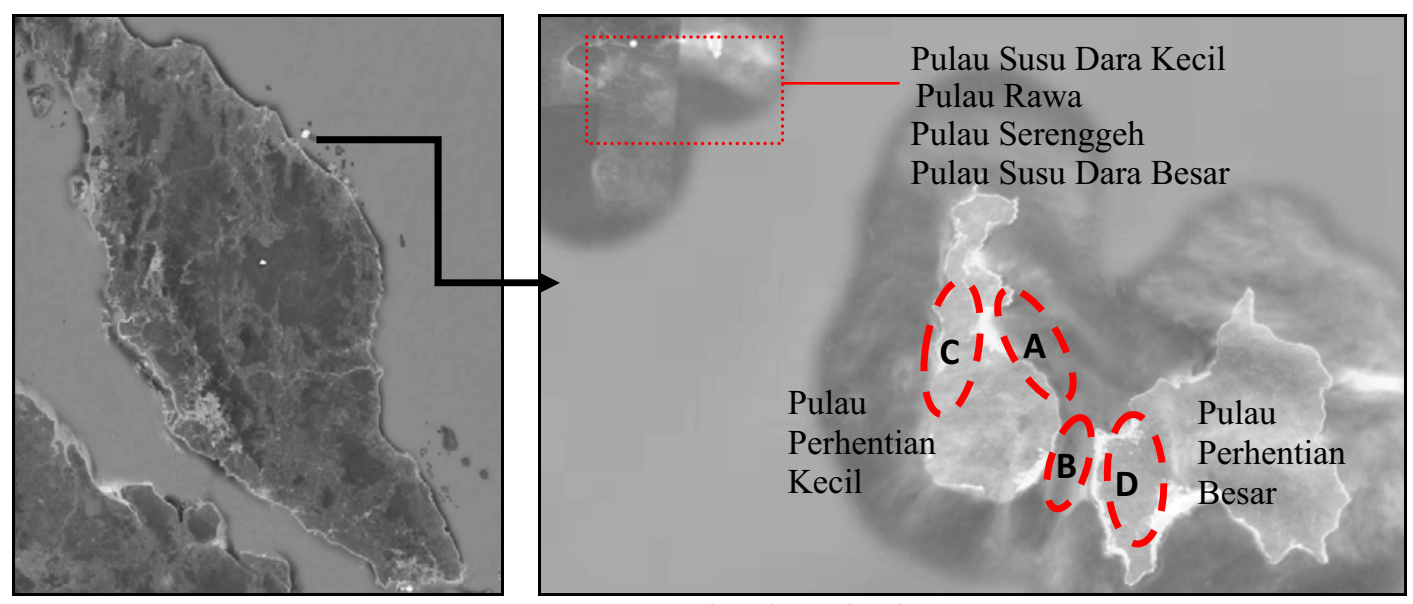

Map 1. Perhentian Island

Source: [6]

Varieties of accommodation were built in both Perhentian Besar and Kecil to accommodate the increasing demand by tourists. Today, there are 42 resorts and chalets with total 1000 rooms approximately provided. Further, many people from the mainland reside on this island to work with the lodge operators resulted in the expansion of the settlement area. There is only one settlement area in this island called Kampung Pasir Hantu with 2163 people. The growth of the tourism sector has been benefiting both local community and tourism operators (lodge operators, boatmen, small entrepreneur and so on) extremely within these six months. However, this is not only benefiting them but also brings negative impacts to the society and the environment in the long run. Based on recent observation on Pulau Perhentian, there are many issues or pressures caused by the development of 
tourism especially on the physical elements such as solid waste management, water supply, electricity supply, sewage management, water pollution and hill erosion. As suggested by [7], the carrying capacity evaluation seems to be a useful concept to support the definition of local management strategies and plans for sustainable tourism especially in investigating the physical and managing limits of tourism system. The purpose of the evaluation of carrying capacity of the destination is the measurement of the threshold over which alteration due to human activities becomes unacceptable for the resource recovery [8]. Consequently, this paper presents on the assessment of physical carrying capacity related issues in Perhentian. It aims to evaluate the destination characteristics that contribute to the physical carrying capacity related issues using a criteria matrix.

\section{Literature review}

According to [9], the host communities seek to attract tourists to their area because of the industry's potential for improving existing economic and social conditions (i.e., the hosts' quality of life). Besides, "tourism generates jobs, wealth and revenues for government" [10, p.36]. Moreover, the increasing numbers of tourist arrivals were resulted in the development of tourist infrastructure, accommodation, recreation centre, transportation and so on as to ensure a high level of satisfaction of tourist during their stay in a destination [11]. Ironically, the development of extensive infrastructure such as jetty, resorts and airports would destruct the island's ecological environment although it was intended to support an increased number of tourists [12]. On the other hand, the uncontrolled tourism development can reduce the satisfaction levels of both tourists and residents [13]. For example, massive number of visitors in a place at the same time would cause overcrowding and unpleasant environment for both of them especially in small island like Perhentian. Indeed, the increasing threats, such as coastal development, collection of threatened species, ornamental trading, destructive fishing, over exploitation for seafood and ornamental species, pollution and irresponsible tourism, have led to the depletion of the biodiversity resources in the region [2].

Perhentian can be categorized as a small island with limited resources and suitable only for smallscale tourist development [14]. Commonly, small islands' development and their impacts are very different from large islands and their adjacent mainland, mostly because of the limitations of their small sizes and limited resources [15]. According to [16], the insular geography and fragile environmental and ecological characteristics are the trouble facing by many small islands. He describes that the fragile marine environment, coastal zones and island ecosystems are susceptible to impacts from natural hazards, impacts of the continual physical change brought about by the relentless drive of globalization and international economic growth, leading to external global impacts from climate change and sea level rises. At the end, the "deterioration of the resources makes less attractive the destination, causing a progressive decrease of tourism, till a complete decline of the tourist destination with negative effects on its economy" $[13, \mathrm{p}$. 1]. Therefore, maintaining and enhancing the existing resources is essential to prolong a tourist destination.

Carrying capacity is a tool to measure the sustainability, and measuring the physical elements is an approach of its assessment [17]. Also, it is a scientific concept that helps to identify the maximum acceptable level of human activities, population growth, land use and physical development that can be sustained by the area under investigation without causing irreversible damage to the environment which is useful for operational approaches oriented to decision-making [8]. Furthermore, the assessment of carrying capacity is used as a sign of tourism impact on space and the environment [18]. It represents an important component of planning spatial development in tourism, and is one of the mechanisms for establishing standards for sustainable tourism [18]. Moreover, the analysis of tourism carrying capacity regarding natural resources and infrastructures will allow for an evaluation of the possibility of development for the destinations in the future; the evaluation is made considering the capacity of the current system of facilities and infrastructures, in the perspective of avoiding new building (such as excessive urbanization and land use) [8]. 


\subsection{The framework of physical carrying capacity assessment}

The carrying capacity comprises most of the measurement of sustainability indicator as suggested by [18, p.110-111] like resource use, waste, pollution, local production, access to basic human needs, access to facilities, freedom from violence and oppression, access to the decision-making process and diversity of natural and cultural life. On the other hand, the [20] recommends several indicators based on specific areas like rural, coastal, island, protected area, mountain resort and urban area. The indicators for island have more priority on the natural environment and biodiversity; energy; water; waste; cultural heritage; tourism infrastructure; land and landscape. Meanwhile, the capacity levels are majorly influenced by the characteristics of the tourists and the characteristics of the destination area and its population, thus it requires an appropriate framework that considers the relationship between both of them [18, 20-21]. As suggested by [21], the conceptual framework of tourism assessment should begin with identifying the demand by tourist, follow by identifying their movements and destinations. After that, the impact will be evaluated after the carrying capacity to take place. The last but not least, the evaluation will be made towards formulating the actions for managing purposes. But for this study, the focus will be on the environment, one of the destination characteristics. This include the topography (mountains, rivers, and sea); environmental processes (sunshine, temperature, precipitation, photosynthesis, and erosion); soil, vegetation, flora and fauna [21].

There are many formulas to calculate the physical carrying capacity of a destination. Commonly, it is about the number of visitors or users that at a given time, a physical environment can support [22]. Other examples include number tourist that can be at the beach in one time; number of accommodations (beds or rooms) in an area, the consumption of utilities, amenities or facilities. Again, it has to consider the characteristics of the destination before further investigation on the carrying capacity can be done. This study aims to evaluate the destination characteristics of Perhentian that contribute to the physical carrying capacity related issues using a criteria matrix. The criteria matrix is an approach of calculating the variables or criteria of a given subject. Basically, a matrix will give a certain weight to the selected indicator or criteria. In the tourism sector, the criteria matrix appears very useful in evaluating, understanding and managing the development state. In fact, "It assists in the definition of a set of essential indicators for comprehensive sustainability assessment of tourism destinations" [23, p.607\& 609].

\section{Methodology}

The assessment of physical carrying capacity for Perhentian consists of several steps. It begins with an overview of tourism development in Perhentian (the historical background, attractions, physical development, etc) from various sources. Next, the literature review will derive with relevant indicators for small islands like Perhentian such as water; waste; sewage; energy; landscape and architecture; transportation and mobility; as well as space, density and intensity. Besides that, the measurement approach based on criteria matrix also has been identified. It will evaluate the availability or quantity, as well as the condition or quality perspective (either positive or negative) based on personal judgement by referring to the formulated matrix (See Table 1). Then, both Perhentian Besar and Kecil were zoned into four groups to specify the area for observation. Dynamic tourism activities and physical development become the main criteria in identifying the zoning. Subsequently, each indicator will be evaluated in every zone by direct observation. The observation was conducted on the $13^{\text {th }}$ until $20^{\text {th }}$ of May 2014, covered both island (See Map 1).

Finally, the given mark will indicate the issues into three color codes; green $(\mathrm{G})$, yellow $(\mathrm{Y})$ and red (R). These colors specify the condition of the destination. The green color indicates the excellence level of cleanliness, systems or services; an adequate supply (quantity and quality) of facilities and infrastructure, absent of environmental issues like pollution, erosion and so on with the mark between 80 up to 100 . Meanwhile the yellow signifies the mark between 41 and 79 . Then, the red shows an alarm of tourism development towards the physical environment with the score between 0 and 40 . The low score indicates improper management of solid waste, sewage system, cleanliness and others. 


\section{ICTR}

Table 1. Criteria matrix

\begin{tabular}{|c|c|c|c|}
\hline Matrix & Availability / Quantity (Positive) & Availability / Quantity (Negative) & Condition / Quality \\
\hline $\mathbf{1 .}$ & Absent & Abundance & Very Poor \\
\hline $\mathbf{2 .}$ & Several / Limited & A lot of & Poor \\
\hline $\mathbf{3 .}$ & Sufficient & Several & Good \\
\hline $\mathbf{4 .}$ & Oversupply / Abundance & Absent & Excellent \\
\hline
\end{tabular}

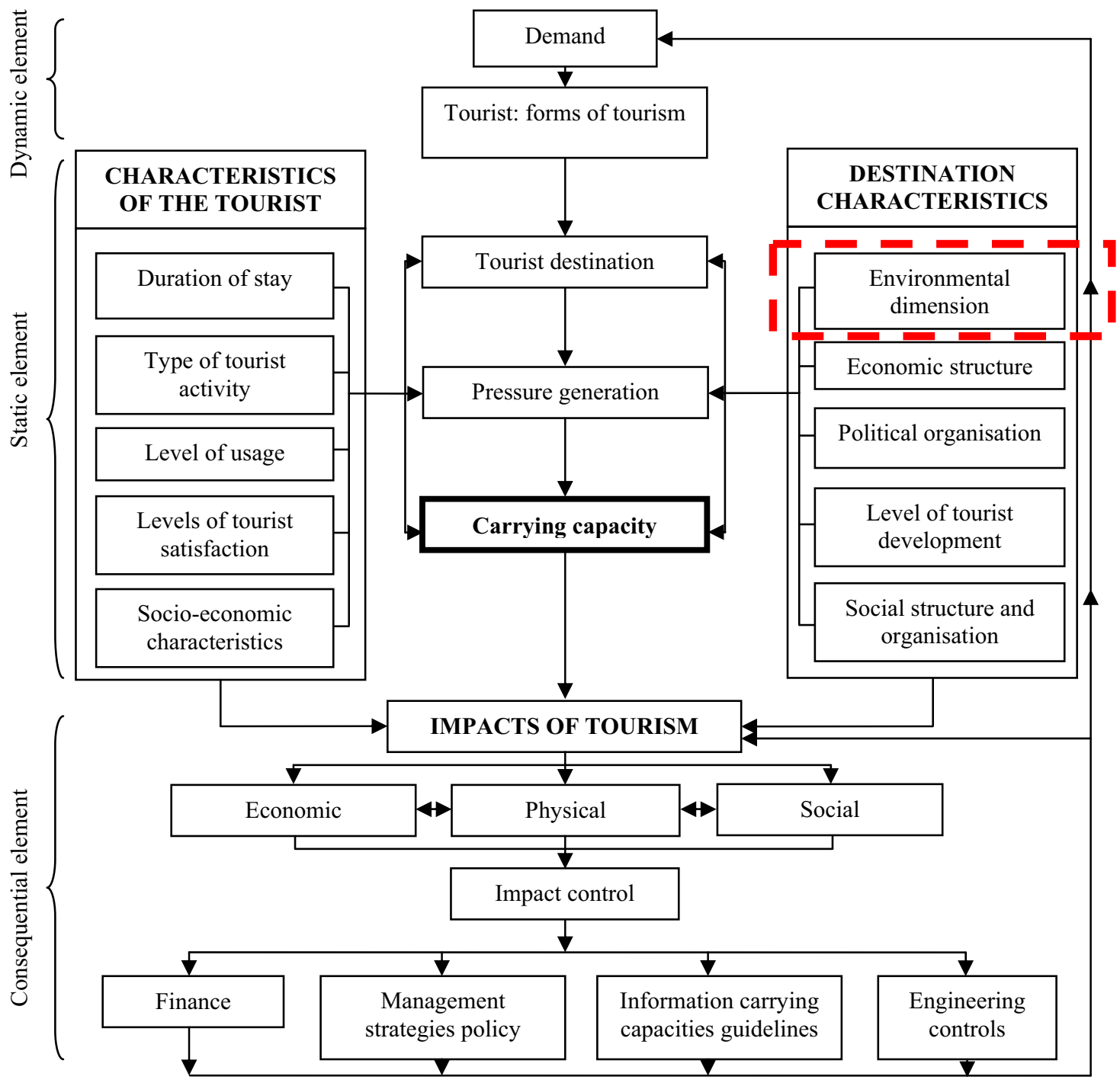

Figure 2. A Conceptual Framework of Tourism

Source: [21], p.15

\section{Findings and discussion}

The physical carrying capacity related issues have been evaluated in details according to specific zones (A, B, C, D) as to ensure the evaluation is useful for monitoring purposes. Generally, the score for every zone are similar fairly. The score for the quality and quantity of power and water supply for 
instance has no difference (sufficient for all). Though many lodge operators do not provide 24 hours electricity because they are using private generators, but it has less effect on tourist activities. Also, the matrix helps to identify the criteria that need more attention such as the quality of sea water. Even if the given marks are based on direct observation, yet the visibility is one of the quality aspects. Also, several sources of sea water pollution have been spotted; direct discharge of waste water and debris from the construction sites (new mosque and low cost houses). Besides, all accommodation establishments are using the septic tank. The problem occurs during heavy rainy days, whenever the sewage waste overflowed to the sea; it left the unpleasant smell of the surrounding area especially in zone A and C. Overall, the cleanliness of the beach area is satisfied except at the Zone A. As it is a lively place for tourist activities like party and beach sports, thus adequate trash bins should be provided.

Table 2. Criteria matrix for Pulau Perhentian Besar and Kecil

\begin{tabular}{|c|c|c|c|c|c|}
\hline \multirow[b]{2}{*}{$\begin{array}{l}\text { Criteria/ } \\
\text { Indicator }\end{array}$} & \multirow[b]{2}{*}{ Item } & \multicolumn{4}{|c|}{ Zone } \\
\hline & & $\begin{array}{c}\text { A } \\
\text { (Long } \\
\text { Beach) } \\
\end{array}$ & $\begin{array}{c}\text { B } \\
\text { (Kg. Pasir } \\
\text { Hantu) } \\
\end{array}$ & $\begin{array}{c}\text { C } \\
\text { (Coral } \\
\text { Bay) } \\
\end{array}$ & $\begin{array}{c}\text { D } \\
\text { (Perhentian } \\
\text { Besar) } \\
\end{array}$ \\
\hline \multicolumn{6}{|l|}{ Water Body } \\
\hline \multirow{2}{*}{$\begin{array}{l}\text { Sea } \quad \text { Water } \\
\text { Quality }\end{array}$} & Visibility of sea water & 2 & 2 & 2 & 3 \\
\hline & Floating material on sea water & 2 & 2 & 3 & 2 \\
\hline \multirow{3}{*}{$\begin{array}{l}\text { Availability of } \\
\text { resource }\end{array}$} & Quality of water supply & 3 & 3 & 3 & 3 \\
\hline & Quantity of water supply & 3 & 3 & 3 & 3 \\
\hline & Sources of drinking water & 3 & 3 & 3 & 3 \\
\hline \multicolumn{6}{|c|}{ Solid Waste Management } \\
\hline Recycle & Volume of solid waste recycled & 2 & 2 & 2 & 2 \\
\hline Public facilities & Garbage collection point quantity & 1 & 1 & 1 & 1 \\
\hline \multicolumn{6}{|c|}{ Sewage Management } \\
\hline System & Sewage system & 2 & 3 & 2 & 4 \\
\hline \multicolumn{6}{|c|}{ Landscape and Architecture } \\
\hline Condition & Destruction of local architecture & 3 & - & - & - \\
\hline \multirow{2}{*}{$\begin{array}{l}\text { Percentage } \\
\text { coverage }\end{array}$} & Green spaces/ natural reserves & 1 & 1 & 3 & 3 \\
\hline & Construction project & 2 & 1 & 3 & 2 \\
\hline \multicolumn{6}{|l|}{ Beach } \\
\hline $\begin{array}{l}\text { Stability/ Beach } \\
\text { erosion }\end{array}$ & $\begin{array}{l}\text { Soil erosion and space between } \\
\text { building and shoreline }\end{array}$ & 2 & 2 & 2 & 2 \\
\hline Condition & Cleanliness of the beach & 1 & 2 & 3 & 3 \\
\hline \multicolumn{6}{|c|}{ Transportation and Mobility } \\
\hline \multirow{2}{*}{ Availability } & No. of boat transfer & 3 & 3 & 3 & 3 \\
\hline & Boat docking system & 2 & 2 & 2 & 2 \\
\hline \multirow{2}{*}{ Public facilities } & No. of jetty ( 1 or 2 at each zone) & 3 & 3 & 3 & 3 \\
\hline & Condition of the jetty & 2 & 3 & 3 & 2 \\
\hline \multicolumn{6}{|c|}{ Space, Density and Intensity } \\
\hline Crowdedness & Number of tourist per area & 3 & 2 & 2 & 2 \\
\hline Public access & Space available for public activity & 3 & 3 & 3 & 3 \\
\hline \multirow{2}{*}{$\begin{array}{l}\text { Population } \\
\text { concentration }\end{array}$} & Number of local house & 1 & 3 & 1 & 1 \\
\hline & Number of tourist accommodation & 3 & 3 & 3 & 3 \\
\hline \multicolumn{6}{|l|}{ Energy } \\
\hline Availability & Duration use of electricity & 3 & 3 & 3 & 3 \\
\hline \multicolumn{2}{|l|}{ TOTAL } & $50 / 84$ & $50 / 84$ & $53 / 84$ & $53 / 84$ \\
\hline \multicolumn{2}{|l|}{ PERCENTAGE } & $59.5 \%$ & $59.5 \%$ & $63.1 \%$ & $63.1 \%$ \\
\hline \multicolumn{2}{|c|}{ * COLOUR CODE } & $\mathbf{Y}$ & $\mathbf{Y}$ & $\mathbf{Y}$ & $\mathbf{Y}$ \\
\hline
\end{tabular}




\section{Conclusion}

Nowadays, the sustainable tourism development becomes a major concern especially in a sensitive area like a small island. Malaysia itself has so many beautiful islands that attract the tourists' attention around the world. These islands continue to develop as a tourist spot, attracting a continuous number of arrivals [12]. Tourism, either it exists or proposed has a great potential for both positive and undesirable environmental and social cultural impacts to occur [24]. Pulau Perhentian for instance is struggling with many physical carrying capacity related issues such as waste management, supply of accommodation, utilities, facilities and environmental protection. Therefore it requires a systematic approach for monitoring purposes. The conducted evaluation indicates the condition or physical development towards the environment of Pulau Perhentian. It discovers several characteristics of the island that requires further actions like the quality of sea water, the coverage of nature reserve and the quantity of garbage collection point. Moreover, there is an issue of abandoned resorts that might indicate a problem on the management or oversupply matter. In fact, the oversupply of resorts in a small island is actually a waste as it cannot contribute to profit making in fact it ask for unnecessary cost for maintenance" [25]. This study require further explore and synthesize on the appropriate formula or calculation for physical carrying capacity assessment that should incorporate the elements of supply and demand. Moreover, the evaluation should be continued by identifying the characteristics of tourist in Pulau Perhentian. Feasibly, this will contribute in protecting the environment and assisting in developing a sustainable tourism development of small island in Malaysia.

\section{Acknowledgement}

The funding for this project is made possible through the research grant obtained from the Ministry of higher Education, Malaysia under the Long Term Research Grant Scheme 2011 [LRGS Grant No.: JPT.S (BPKI) 2000/09/01/015Jld.4 (67)].

\section{References}

1. Tourism Malaysia, Your Diving Paradise (2004)

2. Marine Environment and Resources Foundation, Inc. Conservation International Philippines and Institute Borneo Marine Research, Universiti Malaysia Sabah, Marine Protected Areas (MPS) Gap Analysis for Philippines and Malaysia (2009)

3. Department of Marine Malaysia, Marine Park, Retrieved from http://www.dmpm.nre.gov.my (2014)

4. Local Authority of Besut. Pulau Perhentian (no date).

5. A. Hamzah, M. Hampton, Tourism development and non-linear change in small islands: Lessons from Perhentian Kecil, Malaysia (2011)

6. Google Earth (2014)

7. C. Valentina, S. Serenella. Carrying capacity of tourism system: Assessment of environmental and management constraints towards sustainability. [book auth.] Kasimoglu Murat. Visions for global tourism industry: Creating and sustaining competitive strategies. (2012)

8. C. Valentina, S. Serenella, P.D. Wit, Transactions on Ecology and the Environment, 106 (2007)

9. J. Ap, J.L. Crompton, J of Travel Research, 120-130 (1998)

10. R. Peter, L. Michael, S, L. J, Smith, Tourism (2013)

11. M. Muhibudin, B. Mohamed, OIDA Int J Sust Dev (2012)

12. B. Mohamed, A.P. Mat Som, J. Jusoh, W.K. Yew, Island tourism in Malaysia: The not so good news, 12th Asia Pacific Tourism Association \& 4th Asia Pacific CHRIE Joint Conference (2006).

13. M. Elena, S. Fabrizio, F.F. Lorenzo, A multi-agent simulation approach to sustainability in tourism development. 51 st European Congress of the Regional Science Association International (2011) 
14. P.P. Wong, Tourism vs environment: The case for coastal areas (1993)

15. C.N. Weng, Malaysia Journal of Environmental Management, 10 (2009)

16. C.H. Douglas Sust. Dev. 14, 75-80 (2006)

17. M. Martin, M, Ian, Tourism and sustainability: The new tourism in the third world (2003)

18. J. Dobrica, D, Aleksandra, Turizam (2008)

19. European Commission, Defining, measuring and evaluating carrying capacity in European tourism destinations (2001)

20. M. Alister, W. Geoffrey, Tourism: Economic, physical and social impacts (1998)

21. H. Coccossis, A. Mexa, The challenges of tourism carrying capacity assessment: Theory and practice (2004)

22. M. Tejada, G.C. Malvarez, F. Navas, J Coastal Res, 56, 1159-1163 (2009)

23. S. Karin, K. Lydia, J Sustain Tour, 16 (2008)

24. R.K. Dowling, Community attitudes: tourism development in natural environment [book auth.] S. Singh, D.J. Timothy, R.K. Dowling, 205-228 (2003)

25. B. Mohamed, V, Nair, A. Hamzah, M. Muhibudin, Measuring the tourism carrying capacity of rural destination in Malaysia: A methodological development approach, International Conference on Rural Tourism-ORTE 2013, 819-833 (2013) 